\title{
Cognitive flexibility: exploring students' problem-solving in elementary school mathematics learning
}

\author{
Sri Rahayuningsih ${ }^{1}$, Sirajuddin Sirajuddin ${ }^{2 *}$, Nasrun Nasrun ${ }^{3}$ \\ ${ }^{1}$ Department of Mathematics Education, STKIP YPUP Makassar, Indonesia \\ ${ }^{2}$ Department of Primary School Teacher Education, Universitas Muhammadiyah Makassar, Indonesia \\ ${ }^{3}$ Department of Mathematics Education, Universitas Muhammadiyah Makassar, Indonesia \\ *Corresponding author: sirajuddin@unismuh.ac.id
}

\section{ARTICLE INFO}

Article history:

Received: 20 July 2020

Revised: 16 October 2020

Accepted: 23 October 2020

Published online: 28

December 2020

Published regularly: January

2021

\section{Keywords:}

Cognitive flexibility, mathematical problem solving, fraction

\section{ABSTRACT}

In classroom learning, students need mathematical cognitive flexibility to be able to solve mathematical problems with the various ideas they express. To solve the problems, they must be able to grasp the problem, see it from various points of view, and should not be rigid thinking with one solving method. In fact, the students still lack the ability to think flexibly in solving math problems. This exploration is necessary to determine how to encourage the students' creative problem-solving. The purposive sampling technique is used to select two out of 150 of $4^{\text {th }}$ Grade students who have taken an initial test to measure their creative abilities. Problem-solving worksheet, think-aloud records, and interviews are used as data collection instruments. Then, the data were analyzed using a qualitative descriptive approach. The research instrument is validated by two professors of mathematics. Through a series of revisions based on expert advice, the validity results are said to be feasible for use. To check for reliability, field tests are tested on 10 students who meet the criteria as research subjects. Analysis results indicate that cognitive abilities involve cognitive processes in the form of the ability to assess process by looking for patterns of numbers, mentally compute, estimate, and assess the rationality or reasonableness of calculation results. Other findings on students' cognitive processes in solving math problems include looking for number patterns, carrying out trial-and-error (also called guess-andcheck), and drawing diagrams. Students with cognitive flexibility tend to use trial-and-error when solving mathematical problems.

(C2020 Universitas Muhammadiyah Surakarta

\section{Introduction}

In the neuropsychological, cognitive flexibility is the ability to shift between modes of thinking and adapt to novel or changing environments (Zmigrod et al., 2019). When facing a dynamically changing environment, the actions that a person takes to solve a problem are considered to produce cognitive conflict (Hommel, 2015). On the one hand, actions that are directed at a certain goal seek to be maintained. On the other hand, those actions taken remain sensitive to alternative possibilities, to escape from ineffective goals, and adapt 
flexibly when the environments or internal circumstances change (Zmigrod et al., 2019). Therefore, it requires the ability to think flexibly to solve possible problems that will occur with the increasingly rapid development of the times (Rahayuningsih, 2017). It is stated that the importance of having the ability to think flexibly in solving problems in an increasingly rapidly changing world (Deliyianni et al., 2016).

Problem-solving is one of the main aspects of the mathematics curriculum that is not only applied in Indonesia but also throughout the world. Unfortunately, the results of the study indicate that students have difficulty in solving mathematical problems (Andayani \& Lathifah, 2019; Delyana, 2015; Liljedahl et al., 2020). The vision of mathematics education in Indonesia is to understand mathematical concepts and ideas that are then applied to routine and non-routine problem-solving through the development of reasoning, communication, and connections inside and outside mathematics (Simamora et al., 2018). Surprisingly, students remain weak in problem-solving and view mathematics as one of the difficult and boring subjects to learn and deal with a variety of topics (Bishara, 2016; Subaidi, 2016; Warih et al., 2016). The goal of developing students' problem-solving skills can be achieved if the teacher considers more teaching and learning aspects (Singer \& Voica, 2015). Mathematics education should help and guide students in understanding mathematical concepts, processes, and techniques, and developing the ability to solve various mathematical problems (Santos-trigo \& Gooya, 2015) and most importantly, contributing to life decisions (Singer \& Voica, 2015).

Conventional teaching strategies with demonstrations, exercises, and practice using closed problems with expected solutions are insufficient in preparing students for mathematics of the future (Tan, 2018). Students show a lack of ability to successfully apply their problem-solving skills (Clements \& Sarama, 2011). Mathematical skills taught in schools seem to be an insufficient basis for continuing studies at a further level. Therefore every policymaker, educator, and other stakeholders at all levels of education to seek an explanation (Conway \& Sloane, 2005; Gallagher et al., 2020).

Mathematics is known as the heart of science and mathematical creativity can help students to understand what is happening around them. In general, the context used to look at students 'mathematical creativity is to use mathematical problem solving or in other words an instrument to measure students' mathematical creativity is a math problem-solving sheet (Singer \& Voica, 2015). In the context of problem-solving, Singer assumes cognitive flexibility in students who can propose solutions to new problems that differ from diverse solution strategies, produce novel solutions, and change previous frame of mind. Cognitive flexibility occurs when students can change ideas and approach problems in various ways (Huang et al., 2020).

As one of the brain-based skills needed for humans to effectively carry out or perform tasks and solve problems, cognitive flexibility is necessary during the Covid-19 pandemic (Huang et al., 2020). In classroom learning, students need cognitive flexibility to solve mathematical problems with various ideas. Students must be able to grasp the problem, view it from various points of view, and open their mind to more than one possible solution. When flexible thinking is applied in problem-solving, the mind can change quickly according to the situation. This ability is highly useful in finding a solution.

Several previous studies have examined cognitive flexibility from different perspectives. Deliyianni et al., (2016) stated that the ability to change from one representation to another, procedurally or conceptually, is considered as cognitive flexibility ability. The results of the study revealed that cognitive flexibility and problem- 
solving abilities were the main components of students' thought processes about adding fractions and decimal numbers. The research paper explores students' cognitive flexibility abilities in solving math problems in the midst of the Covid-19 pandemic.

In the current pandemic era, students 'cognitive changes in facing the learning process greatly affect students' ability to complete school assignments (Yang et al., $\underline{2020}$ ).

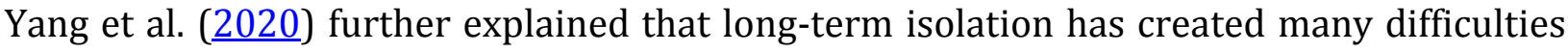
for students in online learning. Among them, students have received a serious stress response due to the issue of the virus in which transmission is very fast (Brooks et al., 2017). In particular, Covid-19 poses a serious threat to student health and causes anxiety and depression, which may affect the learning engagement of isolated students at home (Özdin \& Bayrak Özdin, 2020). Negative emotions such as anxiety can affect student memory and academic progress (Yeh et al., 2007). However, few studies examine students' cognitive flexibility during the Covid-19 pandemic, especially in solving mathematical problems. Thus, such exploration is necessary to determine how to encourage students' creative problem-solving. Individuals who have successfully adapted are those who can be called elastic (Huang et al., 2020), the elastic referred to in the realm of education is known as openness/flexibility in thinking, even cognitive openness or better known as cognitive flexibility.

\section{Research Method}

This research adopts a case study design. Because only certain subjects can be cognitive, this is a particular case. Therefore, a qualitative approach is necessary to produce a good description (Campbell, Thomas, Yin, 2018). In this study, the participants solve mathematical problems, and the qualitative approach is selected to obtain genetic data. The intended natural data describes the participant's condition and obtained without treatment (Creswell, 2012; Fraenkel, et al. 2012).

The participants were two of the 150 of $4^{\text {th }}$ Grade students who were selected using purposive sampling technique because this research is a case study. Therefore, both subjects were explored in depth regarding their cognitive flexibility. Open problem solving tests are used to measure students' creative abilities in solving math problems. The instrument is validated by two mathematics education mathematical problems in various ways; 2) solve math problems quickly and accurately; and 3) use answers classified as unique. In other words, the given questions have never been encountered even though the concepts already exist. The criteria for the subjects in this study are (1) having good communication skills and being able to communicate ideas clearly, such that the participants can effectively express their creativity and (2) willing to be a research subject. Two students are selected as participants and pseudonyms are used to keep their identities confidential.

Student problem-solving instruments are used to measure students' cognitive flexibility abilities and validated previously by experts in the field of mathematics. Singer and Voica ( $\underline{2015}$ ) states that the context used in mathematical problem-solving can measure students' mathematical creativity. In the context of problem-solving, Singer assumes that the students' with cognitive flexibility can propose solutions to new problems that differ from diverse solution strategies, produce novel solutions, and change the previous frame of mind (Singer et al., 2017)

Participants in $4^{\text {th }}$ Grade are requested to solve elementary school mathematics problems. They must complete the following assignments. 
1. A rope is cut $\frac{1}{3}$ part. The remaining piece of rope is $18 \mathrm{~m}$. What is the initial length of the rope? Use various ways to find answers!

2. Determine fractions that lie between $\frac{4}{9}$ and $\frac{5}{9}$. Use various possible solutions!

3. Is $\frac{5}{8}$ or $\frac{7}{12}$ closer to 0.5 ? Use various possible solutions!

This study refer to Singer's theory (Singer \& Voica, 2015; 2017) to analyze the creative problem-solving process of students. In this process, they are able to propose solutions to different new problems ranging from diverse solving strategies, produce the solutions that have never been encountered before, and change the previous frame of mind. We also assume that the cognitive flexibility process occurs when students are able to solve mathematical problems in a variety of different ways that are used unusual/have never been encountered before.

The method used to collect data is Think Out Louds (TOL). Olson et al. (Subanji, 2016) explains that Think Out Loud method aims to study how a person solves a problem, that is when someone solves a problem, then what is thought can be recorded and analyzed to determine the cognitive processes associated with a given problem. Because of the Covid19 pandemic conditions, the process of taking interview data and TOL are conducted through Zoom media. The questions used at the interview are slightly different from the interview guidelines that have been made previously to find the problem more openly and the parties invited to the interview are asked for their opinions.

The results of the transcript and physical behavior exhibited by participants were analyzed with the following steps (Creswell, 2012):

1. Analyzing and examining all available data from various sources: interviews, Think Out Loud videos, and field notes;

2. Carrying out data reduction by making abstractions. Abstraction is an attempt to make a summary of the core, process, and statements that need to be maintained to remain in it;

3. Arranging in units which are further categorized by making coding;

4. Conducting data validity checks, by means of time triangulation; Analysis of interesting things, i.e. behavioral analysis shown by research participants who are unplanned and unrelated to the research objectives; and

5. Interpreting of data/conclusions.

\section{Results and Discussion}

The results show different cognitive abilities between the two students. However, in general, they are able to solve math problems using their cognitive flexibility abilities. They complete the questions given by carrying out four components of the process: assessing the number (bb), mental computation ( $\mathrm{km})$, estimation (e), and assessing the rationality or reasonableness of the calculated results obtained (rk). The following is the completion process carried out by student 1 (Sub1).

\section{Subject 1 (Sub 1)}

The following is the complete process used by Sub1 on TOL for assessing the magnitude of numbers appears on the solution.

Initially, the length of the rope is one part, then cut $\frac{1}{3}$ part, therefore the remaining is $1-\frac{1}{3}=\frac{3}{3}-\frac{1}{3}=\frac{2}{3}$. Subjects are able to say that $\frac{1}{3}$ is smaller than 1 . This process indicates the subject's ability to judge 
the magnitude of the number. Given that the $\frac{1}{3}$ part is initially smaller than the length of the rope, subtract the initial length of the rope by $\frac{1}{3}$ part and finally determine the remaining $\frac{2}{3}$ parts. The process that the subject goes through indicates the subject's ability to perform mental computations and assess the rationality of the calculated calculations. Furthermore, the subject's ability to judge based on also appears in the completion which is done as follows:

$$
\frac{2}{3} \text { parts }=18 \mathrm{~m}
$$

Furthermore, the subject's ability to perform mental computations is followed by the subject's process of assessing rationality by performing a sensible calculation process that appears in the following solutions.

(Both sides are multiplied with $\frac{3}{2}$ to make one part)

$\left(\frac{2}{3} \times \frac{3}{2}\right)$ section $=\left(18 \times \frac{3}{2}\right) \mathrm{m}$

1 part $=27 \mathrm{~m}$

Therefore, the length of the initial rope is $27 \mathrm{~m}$.

Alternatively,

$\frac{1}{3}+\frac{1}{3}+\frac{1}{3}=\frac{3}{3}, \frac{3}{3}=1$, because $\frac{2}{3}=18 \mathrm{~m}$ then $\frac{2}{3}: 2=\frac{1}{3}$ means $18: 2=9$ so that $\mathrm{I}$ obtain

$\frac{1}{3}+\frac{1}{3}+\frac{1}{3}=$ ?

$\left(\frac{1}{3}+\frac{1}{3}\right)$ is $\frac{2}{3}=18 \mathrm{~m}$, then $\frac{1}{3}=9$

Thus, the initial length is $\frac{1}{3}+\frac{1}{3}+\frac{1}{3}=1,9+9+9=27 \mathrm{~m}$.

Therefore, the length of the rope is originally 27 meters.

The results of the answers to the solution of the first subject (Sub1) show that Sub1 was able to express the problem-solving process. It means that the subject has the ability to interpret the problem-solving process in various ways. It is indicate that the subject has the ability of cognitive flexibility in solving mathematical problems. Then, the results of the investigation of the completion process proved that Sub1 was able to assess the magnitude of numbers, perform mental computing, estimate, and assess the rationality or reasonableness of the calculation results obtained. The interview transcript of the problem-solving process is presented as follows.

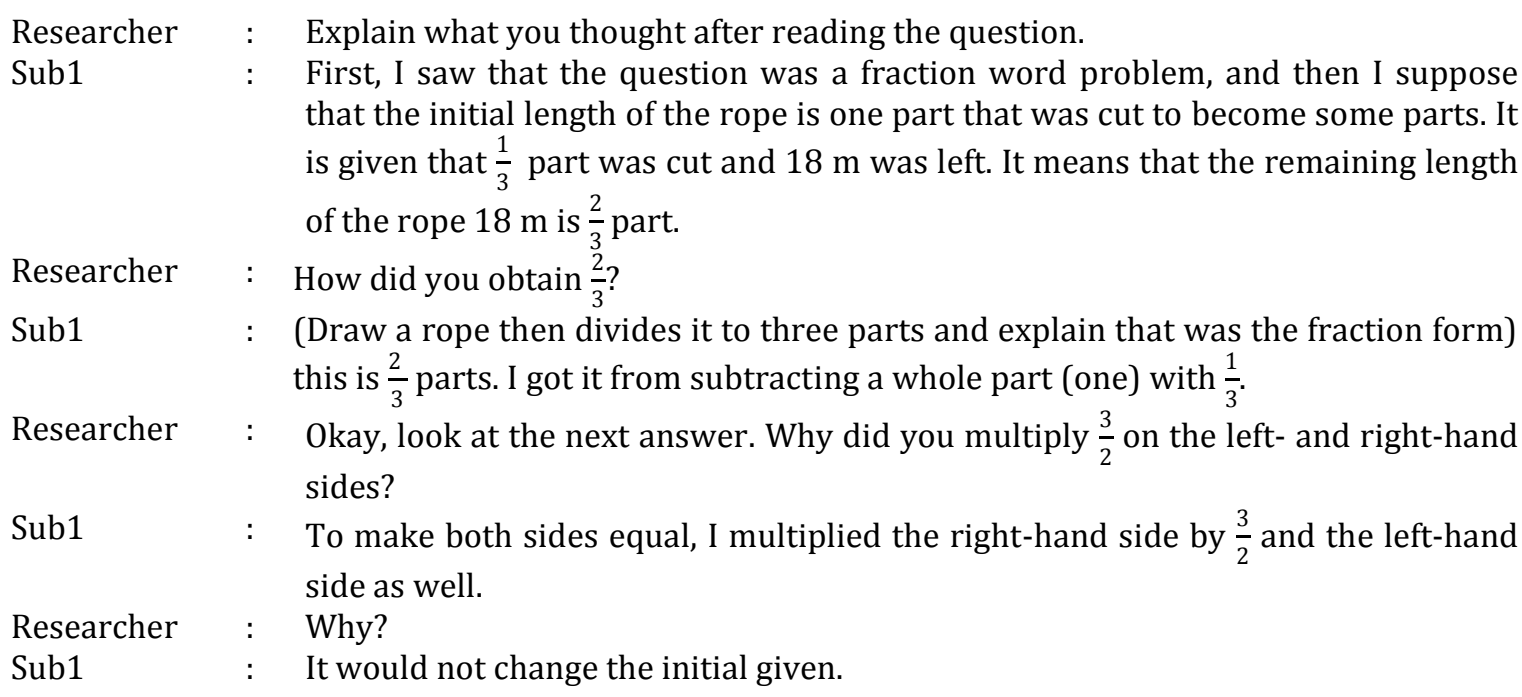

The results of the answers to the solution of the first subject (Sub1) show that Sub1 is able to express more than the problem-solving process. It means that, the subject has the ability to interpret the problem-solving process in various ways. It is indicate that the subject has the ability of cognitive flexibility in solving mathematical problems. Then the 
results of the investigation of the completion of the process proved that Sub1 was able to assess the magnitude of numbers, perform mental computing, estimate, and assess the rationality or reasonableness of the calculation results obtained. The interview transcript of the problem-solving process is presented as follows.

Researcher : Can you tell us what you think after reading the questions above?

Sub1 : At first, I saw that the problem above was a question of fractions. Then I suppose that the length of the original rope was one part that was cut into several parts, and the problem states $\frac{1}{3}$ partwas cut and the remaining part was $18 \mathrm{~m}$ long. This means that the remaining 18 meters are $\frac{2}{3}$.

Researcher : Why $\frac{2}{3}$ ?

Sub1 : (Draws a piece of string then divides it into three parts and explains that this is the shape of the fraction) this is a part which is $\frac{2}{3}$. The process is easy enough to reduce one to one-third of the known part of the problem.

Researcher Alright, try to consider your next answer. Why did you multiply $\frac{3}{2}$ on each section?

Sub1 To make the right-hand section an integral part. The right side is $\frac{3}{2}$, and thus the left is the same.

Researcher Why does it have to be like that?

Sub1 So as not to change the first grade.

\section{Subject 2 (Sub2)}

The second student (Sub2) solves the problem by looking for patterns of numbers, and attempts solutions using pictures (Figure 1).

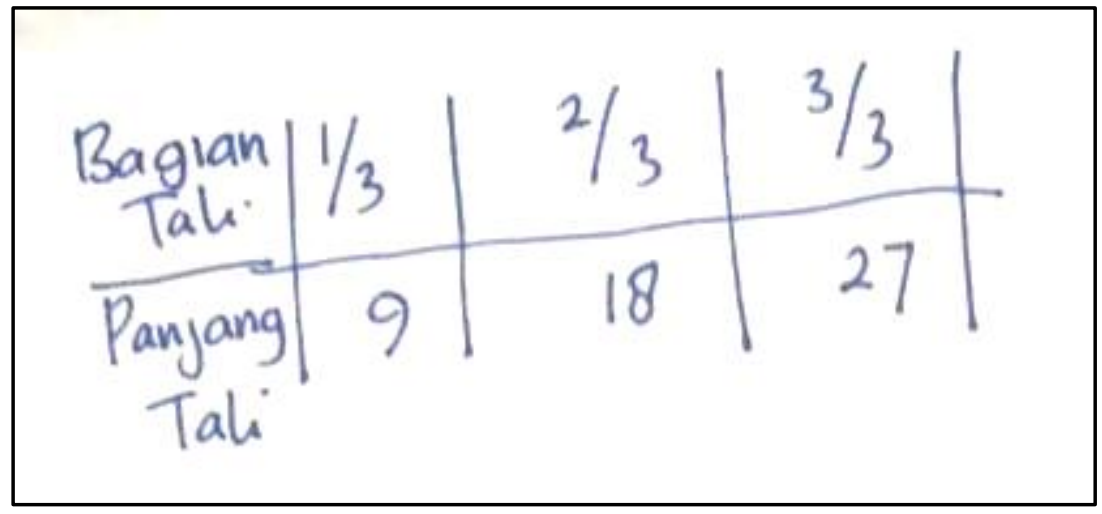

Figure 1. The Sub2 answer on problem 1

Figure 1 indicates the ability of Sub2 to provide different and unusual solutions and possession of cognitive flexibility. She is only provides a sketch of a table image while explaining each computation process. The TOL of the solution of problem 1 is presented as follows.

..." because the length of the rope is 18 meters after being cut $\frac{1}{3}$ part, then the remaining part should be $\frac{2}{3}$. Because a whole part is equal to $\frac{3}{3} \cdot \frac{1}{3}+\frac{1}{3}=\frac{2}{3}$, it is obtained 9 meters of 18 meters. Because half of 18 meters is 9 meters, it means that $\frac{3}{3}$ part is 27 meters. ...hmmm I think a multiple of 9"

Sub2 represents the concept of a mathematical problem by explaining the image, looking for patterns of multiples of 9,9, 18 and 27, making a fractional pattern of $\frac{2}{3}, \frac{2}{3}$ and $\frac{3}{3}$, 
and adding multiples of $\frac{1}{3}$. Sub2 pairs each fraction with the length of the string. Therefore, the initial length is 27 meters.

\begin{tabular}{|c|c|c|}
\hline Researcher & : & Do you have other programs to get the same results? \\
\hline Sub2 & : & $\begin{array}{l}\text { Because } \frac{2}{3} \text { is equal to } 18 \text { meters, then } \frac{1}{3} \text { is } 9 \text { meters, Therefore, } \\
\frac{1}{3} \times 3=9 \times 3 \text { so } \frac{3}{3}=27 \text { or the initial is } 27 \text { meters. }\end{array}$ \\
\hline Researcher & : & Why it have to be multiplied by 3 ? \\
\hline Sub2 & : & $\begin{array}{l}\text { To make } \frac{3}{3}=1 \text {, it must be multipled by } 3 \text {, as well as a rope length of } 9 \\
\text { meters multiplied by } 3 \text { so that the initial length obtained before cutting } \\
\text { is } 27 \text { meters }\end{array}$ \\
\hline
\end{tabular}

The similar process in solving the problem by Sub2 is seen in the answer of the problem 2. The solution of Sub2 on problem 2 is presented in Figure 2.

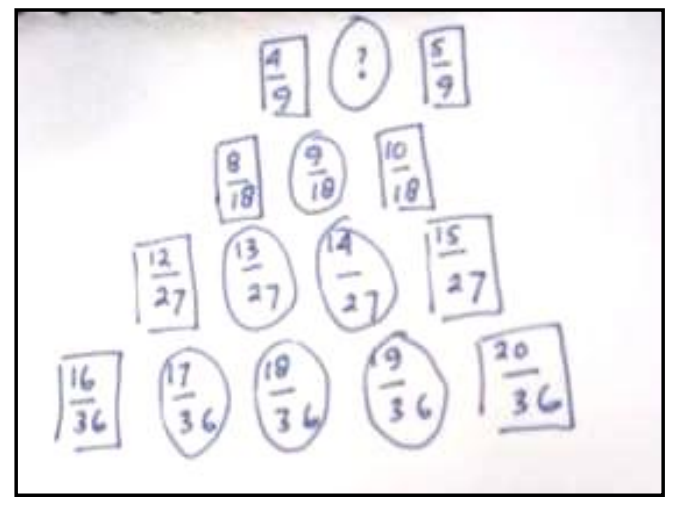

Figure 2.The Sub2's answer on problem 2

In Figure 2, Sub2 completes the problem by making a number pattern and marking each answer with a circle. A square sign indicates the same fraction value. Drawing from perspectives and representations according to the illustration of the problem, Sub2 concludes that the higher the denominator value of the two known fractions, the greater values between the two fractions. The TOL of the solution of problem 2 is presented as follows.

... “ $\frac{4}{9}$ and $\frac{5}{9}$, looking for fractions that exist in between. I have to find similar fractions through the least common multiple of 9 , that was 18 . Thus, I obtained $\frac{8}{18}$ and $\frac{10}{18}$, and finally reached $\frac{9}{18}$, the fraction between both fractions. Looking for the denominator with a multiple of 9 , that was 27 , then it is obtained $\frac{13}{27}, \frac{14}{27}$. I tried with denominator 36 , and it is obtained $\frac{17}{36}, \frac{18}{36}, \frac{19}{36}$."

The solution of Sub2 for the third problem is presented in Figure 3. It shows that Sub2 completes by the process of finding the value of a fraction, which is $0.5=\frac{1}{2}=\frac{12}{24}$. The next step is looking for a value of fraction by equalizing the denominator of two fractions, $\frac{5}{8}$ $=\frac{15}{24}$ then $\frac{7}{12}=\frac{14}{24}$. Then next order the fractions are $\frac{12}{24}, \frac{13}{24}, \frac{14}{24}, \frac{15}{24}$ so that $\frac{7}{12}$ is closer to 0.5 . The solution used by Sub2 is rarely used by students. The cognitive process that occurs when solving these problems, Sub2 is trying to solve in various perspectives, recalling the concept of fractions that had been encountered before, and re-examining the answers obtained. 


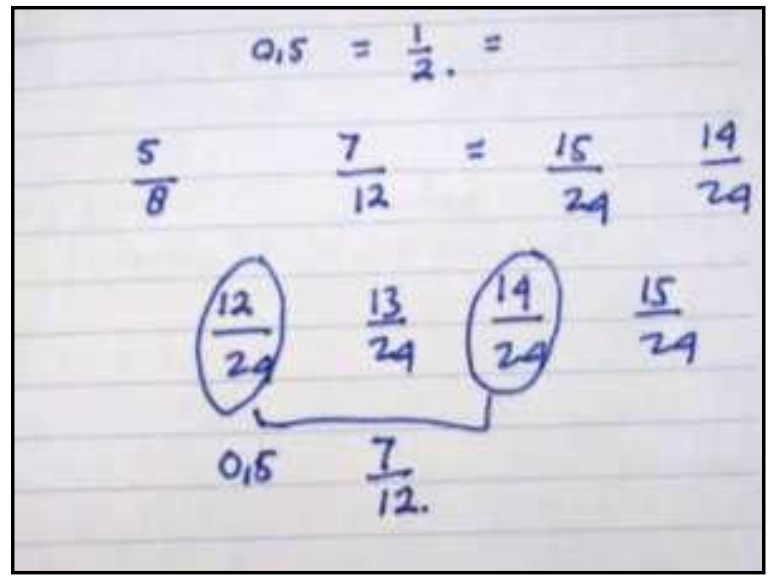

Figure 3. The Sub2's answer on problem 3

The results show that cognitive flexibility involves cognitive processes in the form of the ability to assess the number of numbers, mentally compute, estimate, and assess the rationality or reasonableness of the calculation results. In line with Hadi (2015), cognitive flexibility can be observed when the subject performs four process components: namely assessing the number of numbers, mental computation, estimation, and the rationality or reasonableness of the calculation results.

Understanding number magnitudes occur when students can compare numbers, sort them, recognize two numbers that are closer to the third number, and identify them between two given values. This finding is in line with the opinion (Thompson, 1993) that "someone understands a quantity by understanding the quality of an object if someone understands how to measure it".

When a subject solves a given problem, cognitive processes include the ability to look for patterns of numbers, carry out trial-and-error (also known as guess-and-check), and solve using diagram drawings. Clements and Sarama (2007) suggest that algebra begins with pattern searching. Identifying patterns helps students bring order, cohesion, and certainty to situations that appear unorganized and allow one to recognize relationships and arrive at generalizations. Patterns can serve as a support to be able to distinguish predictability from randomness. They can develop algebraic insight when learning the rules of substitution and applying them without regard to specific items involved in patterns (patterns that emerge can show relationships with each other even though they differ in real nature). Therefore, pattern recognition and analysis are important components of children's intellectual development because they can provide a basis for the development of algebraic thinking (Clements \& Sarama, 2007).

The increased recognition of patterns apparently involves increased recognition of differences and similarities in pattern elements (Papic, 2007). In addition, increased recognition of alternating patterns can increase the abstraction of a reciprocal relationship and generalize the relationship to a new form (for example, from color to shape or size; Ljung-Djärf et al., 2013). If a child provides the same name for a change to a new form that is disparate (e.g., color and shape), then the child has named a variable, which is characteristic of algebraic thinking (Pasnak et al., 2016).

Trial-and-error (also known as guess-and-check) and drawing diagrams are also observed in the problem-solving. Yew et al. (2016) suggested that problem-solving involves the ability to use simple cases; carry out trial-and-error (also known as guess-and- 
check); draw diagrams; identify patterns; make a table, chart, or systematic list; use simulation; use an analogy; work backwards; apply logical reasoning; and use algebra. Resolving a mathematical case or problem also requires sensitivity, reasoning (Saleh et al., $\underline{2019}$ ), and creative thinking (Nugroho et al., 2020). In solving problems, students use the four basic operations in mathematics and manipulate all given data, then stop when they feel they have arrived at a reasonable answer based on their estimations (Tan, 2018). The oldest strategy used in problem-solving is trial-and-error, which is not a systematic approach but is applied to situations when solutions to the problem cannot be found. Being considered as the opposite of trial-and-error strategy, a systematic exploration is an approach that involves such steps as hypothesis testing, planning, and evaluating the results of an action (Van Der Linden et al., 2001). Therefore, students with cognitive flexibility tend to use trial-and-error when solving problems.

\section{Conclusion}

The conclusion of this study is the cognitive flexibility involves cognitive processes in the form of the ability to assess the number of numbers, mental computing, estimation, and assess the rationality or reasonableness of the calculation results obtained. When students solve problems, the cognitive processes involved include the ability to look for patterns of numbers, carry out trial-and-error (also known as guess-and-check), and draw diagrams. Students with cognitive flexibility tend to use trial-and-error when solving problems. The ability to solve mathematical problems requires the ability to think flexibly in exploring various alternative ways or solutions. Meanwhile, the activity of solving mathematical problems provides problematic situations that become triggers for the development of students' creative potential. This linkage needs to be explored as a basis of developing these two capabilities. The limitation of this study is the difficulty of finding research subjects because the situation does not allow the researcher to go to school so that the selection of subjects is less varied. Therefore, the information obtained is very little because it is difficult to reveal information in depth about the cognitive processes that occur in the process of solving math problems. Besides, the interview in this research is conducted virtually. For further research, it is suggested to carry out the research related to the ability to think flexible at a higher level, for example in college students with more unique subjects.

\section{Acknowledgement}

The authors are thankful to STKIP YPUP Makassar and Universitas Muhammadiyah Makassar. The author also thanks all participants involved in this study, especially all fourth-grade students of elementary schools in Makassar.

\section{Bibliography}

Andayani, F., \& Lathifah, A. N. (2019). Analisis Kemampuan Pemecahan Masalah Siswa SMP dalam Menyelesaikan Soal Pada Materi Aritmatika Sosial. Jurnal Cendekia: Jurnal Pendidikan Matematika, 3(1), 1-10. https://doi.org/10.31004/cendekia.v3i1.78

Bishara, S. (2016). Creativity in unique problem-solving in mathematics and its influence on motivation for learning. Cogent Education, 3(1). https://doi.org/10.1080/2331186X.2016.1202604

Brooks, S. K., Dunn, R., Amlôt, R., \& Rubin, G. J. (2017). A systematic, thematic review of 
social and occupational factors associated with psychological outcomes in healthcare employees during an infectious disease outbreak. Journal of Occupational and Environmental Medicine, 60(3), 248257.https://doi.org/10.1097/JOM.0000000000001235

Campbell, Donald Thomas; Yin, R. K. (2018). Case study research and applications: Design and methods (6th ed). California: SAGE Publications.

Clements, D. H., \& Sarama, J. (2007). Early Childhood Mathematics Learning. 1, 461-55. Retreived from https://www.researchgate.net/publication/258933144

Clements, D. H., \& Sarama, J. (2011). Early childhood teacher education: The case of geometry. Journal of Mathematics Teacher Education, 14(2), 133-148. https://doi.org/10.1007/s10857-011-9173-0

Conway, P. F., \& Sloane, F. C. (2005). International Trends in Post-Primary Mathematics Education: Perspectives on Learning, Teaching and Assessment (Research Report). Retreived

from https://ncca.ie/media/1491/international trends in postprimary mathematics edu cation rr5.pdf

Creswell, J. W. (2012). Educational research: Planning, conducting, and evaluating quantitative and qualitative research (4th Edition). Boston, MA: Pearson.

Deliyianni, E., Gagatsis, A., Elia, I., \& Panaoura, A. (2016). Representational Flexibility and Problem-Solving Ability in Fraction and Decimal Number Addition: A Structural Model. International Journal of Science and Mathematics Education, 14, 397-417. https://doi.org/10.1007/s10763-015-9625-6

Delyana, H. (2015). Peningkatan Kemampuan Pemecahan Masalah Matematika Siswa Kelas VII Melalui Penerapan Pendekatan Open Ended. Lemma, 2(1), 26-34. Retreived from http://ejournal.stkip-pgri-sumbar.ac.id/index.php/jurnallemma/article/download/523/318

Fraenkel, J. R., Wallen, N. E., \& Hyun, H. H. (2012). How to Design and Evaluate Research in Education (8th ed). New York: McGraw-Hill.

Gallagher, A. L., Murphy, C. A., Conway, P. F., \& Perry, A. (2020). Establishing premises for inter-professional collaborative practice in school: inclusion, difference and influence. Disability and Rehabilitation, $0(0), \quad 10$. https://doi.org/10.1080/09638288.2020.1725154

Hadi, S. (2015). Number Sense: Berpikir Fleksibel. Math Didactic: Jurnal Pendidikan Matematika, 1(1), 1-7. Retreived from http://eprints.ulm.ac.id/id/eprint/2128

Hommel, B. (2015). Between Persistence and Flexibility: The Yin and Yang of Action Control. Advances in Motivation Science, 2, 33-67. https://doi.org/https://doi.org/10.1016/bs.adms.2015.04.003

Huang, R., Tlili, A., Chang, T. W., Zhang, X., Nascimbeni, F., \& Burgos, D. (2020). Disrupted classes, undisrupted learning during COVID-19 outbreak in China: application of open educational practices and resources. Smart Learning Environments, 7(1). https://doi.org/10.1186/s40561-020-00125-8

Huang, R., Yang, J., \& Chang, T.-W. (2020). Handbook on Facilitating Flexible Learning During Educational Disruption: The Chinese Experience in Maintaining Undisrupted Learning in COVID-19 Outbreak. Beijing: Smart Learning Institute of Beijing Normal University

Liljedahl, P., Santos-Trigo, M., Malaspina, U., \& Bruder, R. (2020). Problem solving in mathematics education. In G. Gabriele Kaiser, Faculty of Education, University of Hamburg, Hamburg (Ed.), Research in Mathematics Education. 
https://doi.org/10.1080/14794802.2020.1731577

Ljung-Djärf, A., Brante, M. H. O., \& Brante, E. W. (2013). Patterns of Variation: A Way to Support and Challenge Early Childhood Learning? Creative Education, 04(07), 33-42. https://doi.org/10.4236/ce.2013.47a1005

Mosimege, M. (2016). The Role and Importance of language in Ethnomathematical Research and Implications for Mathematics teaching and learning. 13th International Congress on Mathematical Education Hamburg, July, 24-31. Retreived from https://www.researchgate.net/publication/306358855

Mursidik, E. M., Samsiyah, N., \& Rudyanto, H. E. (2015). Creative Thinking Ability in Solving Open-Ended Mathematical Problems Viewed From the Level of Mathematics Ability of Elementary School Students. PEDAGOGIA: Journal of Education, 4(1), 23-33. https://doi.org/10.21070/pedagogia.v4i1.69

Nugroho, A. A., Nizaruddin, N., Dwijayanti, I., \& Tristianti, A. (2020). Exploring students' creative thinking in the use of representations in solving mathematical problems based on cognitive style. JRAMathEdu (Journal of Research and Advances in $\begin{array}{lll}\text { Mathematics 202-217. } & \text { Education), }\end{array}$ https://doi.org/10.23917/jramathedu.v5i2.9983

Özdin, S., \& Bayrak Özdin, S. (2020). Levels and predictors of anxiety, depression and health anxiety during COVID-19 pandemic in Turkish society: The importance of gender. International Journal of Social Psychiatry, 66(5), 504-511. https://doi.org/10.1177/0020764020927051

Papic, M. (2007). Promoting Repeating Patterns with Young Children - More Than Just Alternating Colours! Australian Primary Mathematics Classroom, 12(3), 8-13. https://search.informit.com.au/documentSummary;dn=135529953955178;res=IELH $\underline{\mathrm{SS}}$

Pasnak, R., Schmerold, K. L., Robinson, M. F., Gadzichowski, K. M., Bock, A. M., O’Brien, S. E., Kidd, J. K., \& Gallington, D. A. (2016). Understanding number sequences leads to understanding mathematics concepts. Journal of Educational Research, 109(6), 640646. https://doi.org/10.1080/00220671.2015.1020911

Rahayuningsih. (2017). Persepsi keterampilan berpikir kreatif calon guru matematika di Universitas Muhammadiyah Makassar dalam memecahkan masalah matematika geometri. Jurnal Integral Matematika dan Pembelajarannya, 5(1), 22-31. https://core.ac.uk/download/pdf/229359927.pdf

Saleh, H., Untari, R. S., Susilo, J., Mu'alimin, \& Sirajuddin. (2019). Student's Deductive Reasoning: Playing Detective Role In an Online Game. International Journal of Innovative Technology and Exploring Engineering, 8(8), 3003-3007. https://doi.org/10.31219/osf.io/typ4k

Santos-trigo, M., \& Gooya, Z. (2015). Mathematical Problem Solving. In: Cho S. (eds) The Proceedings of the 12th International Congress on Mathematical Education. Springer, Cham. https://doi.org/10.1007/978-3-319-12688-3 40

Simamora, R. E., Saragih, S., \& Hasratuddin, H. (2018). Improving Students' Mathematical Problem Solving Ability and Self-Efficacy through Guided Discovery Learning in Local Culture Context. International Electronic Journal of Mathematics Education, 14(1), 6172. https://doi.org/10.12973/iejme/3966

Singer, F. M., \& Voica, C. (2015). Is problem posing a tool for identifying and developing mathematical creativity? Mathematical Problem Posing: From Research to Effective Practice, December 2014, 141-174. https://doi.org/10.1007/978-1-4614-6258-3 7 
Singer, F. M., Voica, C., \& Pelczer, I. (2017). Cognitive styles in posing geometry problems: implications for assessment of mathematical creativity. ZDM - Mathematics Education, 49(1), 37-52. https://doi.org/10.1007/s11858-016-0820-x

Subaidi, A. (2016). Self-Efficacy Siswa Dalam Pemecahan Masalah Matematika. Jurnal Sigma. Universitas Madura, 1(2), 64-68. Retreived from http://ejournal.unira.ac.id/index.php/jurnal sigma/article/download/68/53

Subanji, S. (2016). Teori Berpikir Pseudo Penalaran Kovariasional. Malang: Penerbit Universitas Negeri Malang

Tan, D. A. (2018). Mathematical problem solving heuristics and solution strategies of senior high school students. International Journal of English and Education, 7(3), 1-17. http://ijee.org/yahoo site admin/assets/docs/1.20141632.pdf

Thompson, D. F. (1993). Understanding Financial Conflicts of Interest. New England Journal of Medicine, 329(8), 573-576. https://doi.org/10.1056/NEJM199308193290812

Van Der Linden, D., Sonnentag, S., Frese, M., \& Van Dyck, C. (2001). Exploration strategies, performance, and error consequences when learning a complex computer task. Behaviour and Information Technology, 20(3), 189-198. https://doi.org/10.1080/01449290110047990

Warih, P. D., Parta, I. N., \& Rahardjo, S. (2016). Analisis Kemampuan Koneksi Matematis Siswa Kelas VIII pada Materi Teorema Pythagoras. Prosiding Konferensi Nasional Penelitian Matematika Dan Pembelajarannya [KNPMP I], 377-384. Retreived from http://hdl.handle.net/11617/6978

Yang, X., Zhang, M., Kong, L., Wang, Q., \& Hong, J. C. (2020). The Effects of Scientific Selfefficacy and Cognitive Anxiety on Science Engagement with the "QuestionObservation-Doing-Explanation" Model during School Disruption in COVID-19 Pandemic. Journal of Science Education and Technology, Zhu 2006. https://doi.org/10.1007/s10956-020-09877-x

Yeh, Y. C., Yen, C. F., Lai, C. S., Huang, C. H., Liu, K. M., \& Huang, I. T. (2007). Correlations between academic achievement and anxiety and depression in medical students experiencing integrated curriculum reform. Kaohsiung Journal of Medical Sciences, 23(8), 379-386. https://doi.org/10.1016/S0257-5655(07)70001-9

Yew, W. T.\&Zamri, S. N. A. A. (2016). Problem Solving Strategies of Selected Pre-service Secondary School Mathematics Teachers in Malaysia. MOJES: Malaysian Online Journal of Educational Sciences, 4(2), 17-31. Retreived fromhttps://mojes.um.edu.my/article/view/12646/8137

Zmigrod, L., Rentfrow, P. J., Zmigrod, S., \& Robbins, T. W. (2019). Cognitive flexibility and religious disbelief. Psychological Research, 83(8), 1749-1759. https://doi.org/10.1007/s00426-018-1034-3 